\title{
NEWSLETTER 1999
}

\section{ACCESSIONS TO REPOSITORIES}

The Royal Commission on Historical Manuscripts (HMC) in its annual Accessions to Repositories exercise collects information relating to manuscript accessions from over 200 repositories and record offices throughout the British Isles. This information is then edited and used to produce a number of thematic digests which are distributed for publication in a wide range of learned journals and news sheets, as well as being published in full on the Commission's website (http://www.hmc.gov.uk). It is also added to the computerised indexes to the National Register of Archives (NRA), which the Commission maintains as a central collecting point for information concerning the location of manuscript sources for British history outside of the public records. The NRA, which includes over 42,000 unpublished lists of archives, can be consulted in the public search room at Quality House, Quality Court, Chancery Lane, London WC2A 1HP, whilst the indexes to the NRA are also available via the HMC website. The Commission's staff will also answer limited and specific enquiries by post, fax (0171 831 3550) and e-mail (nra@hmc.gov.uk).

Readers should note that dates for records in this digest are given when known, but that these are covering dates which are not intended to indicate necessarily the presence of records for all intervening years. Records have been included in the digest regardless of whether the deposit has yet been fully listed, and readers are advised to check with the staff of the relevant repository as to whether this, or any other factors, may prohibit availability for research.

\section{Major Accessions to Repositories in 1998 Relating to Roman Catholicism}

\section{NATIONAL, SPECIAL AND UNIVERSITY}

British Library, Manuscript Collections, 96 Euston Road, London NW1 2DB

Sherborne missal (Add MS 74236)

DundeE University Library, Archives AND Manuscripts Department, Tower Building, DundeE DD1 4HN

St Mary's convent, Dundee: records c1950-80

London Guildhall University: Fawcett Library, Calcutta House, Old Castle Street, London E1 7NT

Catholic Women's Ordination: records 1992-98 (5/RCW) 
National Library of Wales, Department of Manuscripts and ReCORDS, ABERYSTWYTh SY23 3BU

Cardiff Roman Catholic Archdiocese: records 1850-1916

(Catholic Records: Diocese of Newport and Menevia)

Pusey House Library, 61 St Giles, Oxford OX1 3LZ

Society of Mary: records

Scottish Catholic Archives, Columba House, 16 Drummond Place, EDINBURGH EH3 6PL

Diocese of Argyll and the Isles (addnl): episcopal records c1970-95

Hugh MacEwan (1874-1984), Monsignor: papers

Preshome Chapel: rules 1803

St John's Deanery, Archdiocese of St Andrews and Edinburgh: records 1951-71

Trinity College Dublin, College Street, Dublin 2

Richardus Phelippus Augnetas: certificate of absolution and reception into a confraternity at Thelsfford, Warwickshire 1492 (11020/2)

Westminster Diocesan Archives, 16a Abingdon Road, Kensington, LONDON W8 6AF

Michael Richards, priest and teacher: papers 1960-97

\section{LOCAL REPOSITORIES IN ENGLAND}

Buckinghamshire Record Office, County Hall, Aylesbury HP20 1UU

Convent of St Katherine of Alexandria, Fulham and Hambledon: records c1887-1998 (D 237)

Cheshire Record Office, Duke Street, Chester CH1 1RL

St Francis's Catholic Church, Chester: council minutes 1984-93 (ERC 11, Acc 05571)

Norfolk Record Office, Gildengate House, Anglia Square, Upper GREEN LANE, NoRwich NR3 1AX

Father Edward Ram of St John Timberhill, Norwich: corresp and papers mainly rel to his introduction of and support for High Church practices 1879-1917 (PB74/142-156)

Tyne and Wear Archives Services, Blandford House, Blandford Square, Newcastle Upon Tyne NE1 4JA

St Bede's Secondary Modern School, South Shields: log book 1921-63 (E/SS6) 
West Sussex Record Office, Sherburne House, 3 Orchard Street, Chichester Correspondence address: County Hall, Chichester PO19 1RN

St Richard's Catholic Church, Chichester: records c1850-1989 (Acc 11,231)

West Yorkshire Archive Service, Calderdale, Central Library, Northgate House, Northgate, Halifax HX1 1UN

Brighthouse Cemetery: list of known Catholic burials (MISC:991)

\section{BIBLIOGRAPHY (Literary)}

Complied by Professor Nancy Pollard Brown. Items are included which provide information on the work of Catholic writers from the midsixteenth century to the mid-nineteenth century and on the history of Catholic manuscripts and printed books. The area of reference is enlarged to include significant studies of major Catholic writers even when these are not primarily concerned with their religious beliefs, general studies on publishers and printers who produced recusant literature, and editions of texts and critical comment on genres and themes to which Catholic writers made important contributions.

ALABASTER, William. Unpublished Works by William Alabaster. Dana F. Sutton, ed. Salzburg Studies in English Literature: Elizabethan and Renaissance Studies 126. Salzburg and Oxford: University of Salzburg, 1997.

BERRY, Boyd M. 'Feminine Construction of Patriarchy, Or, What's Comic in The Tragedy of Mariam', 257-74 in Medieval and Renaissance Drama in England: An Annual Gathering of Research, Criticism, and Reviews, 1995.

BEVAN, Jonquil. 'Ben Jonson's "On my First Son" and the Common Prayer Catechism', Notes and Queries, March 1997, 90-92.

BOUWSMA, William J. 'Hooker in the Context of European Cultural History', 41-57 in Arthur S. McGrade, ed., Richard Hooker and the Construction of Christian Community. Tempe, AZ: Medieval Texts and Studies, 1997. (Same article also printed in Claire McEachern and Debora Shuger, eds., Religion and Culture in Renaissance England. Cambridge University Press, 1997, 142-58.)

BRUMBAUGH, Barbara. 'Cecropia and the Church of Antichrist in Sir Philip Sidney's New Arcadia', Studies in English Literature, Winter 1998, 19-43.

CARY, Elizabeth. The Tragedie of Mariam, The History of the Life, Reign, and Death of Edward II, The History of the Most Unfortunate Prince. The Early Modern Englishwoman. Part I. Printed Writings, 
1500-1640, vol. 2 (Works by and attributed to Elizabeth Cary). Margaret W. Ferguson, introd. Brookfield, VT: Scolar Press, 1996.

CHENEY, Patrick. Marlowe's Counterfeit Profession: Ovid, Spenser, Counter-Nationhood. Universtity of Toronto Press, 1997.

CLARKE, Danielle. 'The Iconography of the Blush: Marian Literature of the 1630s', 111-28 in Kate Chedgzoy, Melanie Hansen, and Suzanne Trill, eds., Voicing Women: Gender and Sexuality in Early Modern Writing. Pittsburgh, PA: Duquesne University Press, 1997.

GALLAGHER, Lowell. 'The Place of the Stigmata in Christological Poetics', 93-115 in Claire McEachern and Debora Shuger, eds., Religion and Culture in Renaissance England. Cambridge University Press, 1997.

GREEN, Ian. The Christian's ABC: Catechisms and Catechizing in England, c.1530-1740. Oxford University Press, 1996.

GREENE, Thomas. 'Ritual and Text in the Renaisssance', 17-34 in Jonathan Hart, ed., Reading the Renaissance: Culture, Poetics, and Drama. New York, N.Y.: Garland, 1996.

GRIFFIN, Benjamin. 'Locrine and the Babington Plot', Notes and Queries, March 1997, 37-40.

HALEY, David B. Dryden and the Problem of Freedom: The Republican Aftermath 1649-1680. New Haven, CT: Yale University Press, 1997.

HISCOCK, Andrew. 'The Hateful Cuckoo: Elizabeth Cary's Tragedie of Mariam, a Renaissance Drama of Dispossession'. Forum for Modern Language Studies, 1997, 97-114.

LOWE-EVANS, Mary. 'Southwell's "Christ's Bloody Sweat". Explicator Summer 1996, 199-202.

LYLY, John. Endymion. David Bevington, ed. (Political allegory based on issue of Catholic loyalty.)

McCULLOUGH, Peter. 'Preaching to a Court Papist? Donne's Sermon before Queen Anne, December 1617', John Donne Journal, 1995, $59-81$.

MAROTTI, Arthur F. 'Southwell's Remains: Catholicism and AntiCatholicism in Early Modern England', 37-65 in Cedric C. Brown and Arthur F. Marotti, eds., Texts and Cultural Change in Early Modern England. Houndmills and London: Macmillan; New York, N. Y.: St. Martin's Press, 1997.

MASLEN, R. W. Elizabethan Fictions: Espionage, Counter-Espionage, and the Duplicity of Fiction in Early Elizabethan Prose Narratives. Oxford: Clarendon Press, 1997.

MINTZ, Susannah B. 'The Crashavian Mother', Studies in English Literature 1500-1900, Winter 1999, 111-29.

MONAHAN, Arthur P. 'Richard Hooker: Counter-Reformation Political Thinker', 203-17 in Arthur S. McGrade, ed. Richard Hooker and the Construction of Christian Community. Tempe, AZ: Medieval and Renaissance Texts and Studies, 1997. 
MOSHER, Sally E. 'Was William Byrd's "The Battell" composed for the Theater?' The Elizabethan Review, Spring-Summer 1995, 32-36.

OLIVER P. M. Donne's Religious Writing: A Discourse of Feigned Devotion. London and New York: Longman, 1997.

PARRISH, Paul. 'Writing about Mother: Richard Crashaw and the Maternal Body', 223-38 in Barbara Ewell and Mary A. McCay, eds., Performance for a Lifetime: A Festchrift Honoring Dorothy Harrell Brown: Essays on Women, Religion, and the Renaissance. New Orleans, LA: Loyola University, 1997.

PLETZEN, Ermien van. 'Fixed and Fluid Imagery: Dryden, Pope, and their Poetic Language of Painting,' Unisa English Studies. Journal of the Department of English, 1995, 14-18.

PRICE, Michael W. " "Offending without Witnes": Recusancy, Equivocation, and Face-Painting in John Donne's Early Life and Writings', Explorations in Renaissance Culture, 1996, 51-81.

SANDERS, Julie. 'A Parody of Lord Chief Justice Popham in The Devil is An Ass', Notes and Queries, December 1997, 528-30.

SHELL, Alison. Catholicism, Controversy and the English Literary Imagination, 1558-1660. Cambridge University Press, 1999.

SKURA, Meredith. 'The Reproduction of Mothering in Mariam, Queen of Jewry. A Defence of "Biographical" Criticism', Tulsa Studies in Women's Literature, Spring 1997, 27-56.

WEBER, Harold. 'A "Double Portion of His Father's Art": Congreve, Dryden, Jonson, and the Drama of Theatrical Succession', Criticism, Summer 1997, 359-82.

WESTERWELL, Bart, ed. Anglo-Dutch Relations in the Field of the Emblem. Symbola et Emblemata: Studies in Renaissance and Baroque Symbolism VIII. Leiden: Brill, 1997.

WHITE, Paul Whitfield. 'Theater and Religious Culture', 133-51 in John Cox and D. S. Kastan, eds., A New History of Early English Drama. New York, N. Y.: Columbia University Press, 1997.

WHITWORTH, Charles. 'Wooing and Wedding in Arden: Rosalynde and As You Like It', Études Anglaises, 1997, 587-99.

WIGGINS, Martin. 'Arundel and Maltravers: A Textual Problem in Edward II', Notes and Queries, March 1997, 42-47.

WRIGHT, Stephanie. 'The Canonization of Elizabeth Cary', 56-68 in Kate Chedgzoy, Melanie Hansen, and Suzanne Trill, eds., Voicing Women: Gender and Sexuality in Early Modern Writing. Pittsburgh, PA: Duquesne University Press, 1997.

\section{FORTHCOMING}

YOUNG, R. V. Doctrine and Devotion in Seventeenth-Century Poetry. Studies in Donne, Herbert, Crashaw, and Vaughan. Studies in Renaissance Literature 2. Woodbridge, Suffolk; Rochester, N. Y.: Boydell and Brewer. (Publication Date 2/12/1999) 


\section{DISSERTATION ABSTRACTS}

PILARZ, Scott Ronald. 'Sacerdotal Self-Fashioning: Priesthood in the poetry of Robert Southwell, S. J., and John Donne'. Dissertation Abstracts International A, March 1997: 3925; City University of New York, 1996. DA 9707143.

RAILEY, Clayton Allen III. 'The Image of the Soul in the Poetry of John Donne, John Dryden, and William Wordsworth'. Dissertation Abstracts International A, February 1997: 3511; Vanderbilt University, 1996. DA 9700464.

TARGOFF, Ramie D. 'The Subject of Prayer: Models of Public Devotion in Early Modern England'. Dissertation Abstracts International A, March 1997: 3953; University of California, Berkeley, 1996. DA 9703295.

WHEELER, Jeffrey Matthew. 'Palpable Fictions: Religious Relics, Populist Rhetoric, and the English Reformation'. Dissertation Abstracts International A, January 1997: 3043; University of Southern California, 1996. DA 9636763.

\section{BIBLIOGRAPHY (Historical)}

Compiled by Dr. Alan Davidson. (Bibliographical information should be sent to Dr. Davidson at 37 Vernon Avenue, Raynes Park, London SW20 8BN).

\section{GENERAL}

ARBLASTER, Paul, 'The Monastery of Our Lady of the Assumption in Brussels (1599-1794)', English Benedictine History Symposium 17 (1999), pp. 54-77.

DOOLAN, Brian, St. George's, Worcester 1590-1999 (Archdiocese of Birmingham Historical Commission, 1999).

MACPHERSON, Duncan, 'Papists Then and Muslims Now', University Lectures in Islamic Studies 1 (1997), pp. 109-26.

MARKHAM, John (ed.), Keeping Faith: 700 years of Catholic Life in Hull 1299-1999 (Highgate Publications, 1999).

MITCHINSON, A. J., The Catholic Family Historian's Handbook (North West Catholic History Soc. 1999).

NOBLE, A. J. (ed.), Henry Taylor's The Ancient Crosses and Wells of Lancashire, vol. 1 Lonsdale Hundred (North West Catholic History Soc. 1999).

OHLHAUSEN, Sidney K., "The First "Pocket Edition" of the Rheims New Testament', Bible Collectors' World 14 iv (Oct. 1998), pp. 6-10. 
OHLHAUSEN, Sidney K., 'Douai-Rheims: a story of faith', Catholic Heritage 8 iv (May/June 1999), pp. 21-23.

PARKINSON, Anne C., A History of Catholicism in the Furness Peninsula 1127-1997 (Centre for North West Regional Studies, Univ. of Lancaster, 1998).

RACAUT, L., "The "Book of Sports" and Sabbatarian Legislation in Lancashire, 1579-616' Northern Hist. 33 (1997), pp. 73-87.

SHEILS, W. J., 'Catholics and their neighbours in a rural community: Egton chapelry 1590-1780', Northern Hist. 34 (1998), pp. 109-33.

\section{TUDOR}

CLARK, Margaret, 'Cross-Border clergy movements in the Reformation West March', Trans. Cumb. and Westmld. Antiq. and Arch. Soc. 98 (1998), pp. 309-12.

SULSTON, Andrew, 'Catholic recusancy in Elizabeth Norfolk', Norfolk Arch. 43 (1998), pp. 98-110.

THOMAS, Phillip V., 'The Privy Council and "Vagrant Runagate" Priests in Elizabethan York', Yorks. Arch. Jnl. 69 (1997), pp. 173-92.

\section{STUART}

CUST, Richard, 'Catholicism, antiquarianism and gentry honour: the writings of Sir Thomas Shirley', Midland Hist. 23 (1998), pp. 40-70.

FERRIS, John, 'The Earlier Churchills', Somerset and Dorset Notes and Queries 34 (1999), pp. 257-72.

PENNINGTON, Janet, 'The persecution of William Penn and his wife', Suss. Arch. Colls. 136 (1998), pp. 203-4.

SHORT, M. J., 'The Corporation of Hull and the Government of James II, 1687-8', Bull. Inst. Hist. Research 71 (1998), pp. 172-95.

\section{HANOVERIAN}

BELLENGER, Aidan, 'The Brussels Nuns at Winchester, 1794-1857', English Benedictine History Symposium 17 (1999), pp. 78-93.

BELLENGER, Aidan (ed.), Downside. A Pictorial History (Downside, 1998).

The Bishops' Register of Confirmations in the Midland District of the Catholic Church in England 1768-1811 and 1816 (Catholic Family History, Occasional publication 3 [1999]).

BUTLER, David, Methodists and Papists. John Wesley and the Catholic Church in the Eighteenth Century (Darton, Longman and Todd, 1995). 
FISHER, Michael J., Alton Towers. A Gothic Wonderland (M. J. Fisher, 35 Newland Ave., Stafford ST16 1NL, 1999).

MARSHALL, B., St. Paul's Catholic Church, Hyde, Cheshire 18481998 (1998). (Obtainable from Rev. D. Maher, St. Paul's Presbytery, St. Paul's Street, Hyde, Cheshire SK14 2JU).

McCLELLAND, V. Alan and HODGETTS, Michael (eds.), From Without the Flaminian Gate. 150 Years of Roman Catholicism in England and Wales 1850-2000 (Darton, Longman and Todd, 1999).

ROBERTS, Ian D., A Harvest of Hope. Jesuit Collegiate Education in England, 1794-1914 (1996).

TALLETT, Frank and ATKINS, Nicholas (eds.), Catholicism in Britain and France since 1789 (Hambledon Press, 1996).

TIMMINS, T.C.B. (ed.), Suffolk Returns from the Census of Religious Worship of 1851 (Suffolk Recs. Soc. [1997]).

\section{IRELAND}

FENNING, Hugh, 'Irishmen ordained at Rome, 1760-1800', Archivium Hibernicum 51 (1997), pp. 16-37.

HADFIELD, Andrew, 'Spenser's description of the execution of Murrough O'Brien: an anti-Catholic polemic?', Notes and Queries 244 (1999), pp. 195-7.

LENNON, Colm, 'Primate Richard Creagh and the beginnings of the Irish Counter-Reformation', Archivium Hibernicum 51 (1997), pp. 74-86.

O'CONNOR, Thomas, 'A Theology Thesis defended by an Irish clerical student in Paris in 1739', Archivium Hibernicum 51 (1997), pp. 3-15.

O'HARA, Tana, 'A vision of hell in early modern Ireland', Archivium Hibernicum 51 (1997), pp. 87-99.

PURCELL, Mary, 'Dublin diocesan archives: Hamilton papers (8)', Archivium Hibernicum 51 (1997), pp. 38-72.

\section{SCOTLAND}

MURPHY, Martin, 'Robert Abercromby, S.J. (1536-1613) and the Baltic Counter-Reformation', Innes Review 50 (1999), pp. 58-75.

\section{WALES}

McCOOG, Thomas M., 'The Society of Jesus in Wales; the Welsh in the Society of Jesus: 1561-1625', Jnl. of Welsh Religious Hist. 5 (1997), pp. 1-27.

MURPHY, Martin, 'Maria's Dreams: The Reckoning', Montgomeryshire Collections 86 (1998), pp. 65-80. 


\section{EARLY IRISH CISTERCIANS}

\section{by Jonathan Gell, O.C.S.O.}

Finbarr Donovan's book is a cri de coeur for Irish Monasticism exemplified in the Cistercian Abbeys of Ireland with a certain stress on County Tipperary and Mellifont in County Louth. What is Irish Monasticism? It is a following of Christ more closely by the Irish people. It is God's Love embracing the Irish people. God sent his apostle Patrick to Ireland to prove and make known His Love for them. Patrick showed a closer way of responding to God's Love. Out of that urge developed Celtic Monasticism. But the urge waned and Malachy was sent by God to enkindle a new closer following of Christ. At first Malachy introduced Augustinian Canons, then Providence took him to Clairvaux and Bernard. And then Malachy introduced the Cistercians to Ireland.

The Cistercians were a reform of the Benedictines. The great drive of the Cistercians was to live the Gospel according to the Rule of St. Benedict more strictly, and all the first Cistercians were followers of the Rule of St. Benedict who wanted to reform it. Citeaux itself and Fountains in England were great illustrations of this. But in Ireland Malachy was introducing to the Irish people a way of living a community life of which they had very little previous experience or knowledge. The Rule of St. Benedict was much more detailed and comprehensive than the Celtic rules of life that they had once known. The Cistercian purpose-built monasteries with communal dormitory, refectory and scriptorium were an innovation. The strict enclosure and vow of stability demanded much. And the office of the abbot was much more stressed and legalised. Obedience was the keynote of this Rule.

So difficulties eventually arose and the monks of Clairvaux came to be considered foreigners. The famous Mellifont Conspiracy rebelled against the authority of the Order. English and Welsh monasteries came to be involved and gave a helping hand: Furness, Stanley, Whitland and Margam. But above all Stephen of Lexington in Nottingham who was Abbot of Stanley in Wiltshire made an Extraordinary Visitation of all the Irish Abbeys. He was a man full of the Spirit and his very arduous journeys proved his genuine love for his brethren.

Nationalistic variances were less marked in the Middle Ages than they are today, and it can be an anachronism to attribute to the early Middle Ages feelings about other nationalities that are common to us today. Christians in particular have always been full of love towards those who begot them in Christ or who brought them again to life in Christ regardless of where they came from. It is always later generations that find an outlet for their rancour in stressing nationalistic differences. England was converted by an Italian monk and an Italian Pope, many say today. 
Father Columcille courageously follows the advice of Pope Leo XIII to historians 'never to shrink from telling the truth, so that their writings may be free from all suspicion of favour or malice' (Saepo Numero 18 August 1883). What, then, should the modern Catholic historian draw out of monastic scandals? Surely it is a matter of God wanting us to appreciate His forebearance, His forgiveness, His mercy, His love for the sinner. Christ came not to call the virtuous, but sinners, (Matthew 9:13). That is to preach Christ.

But what of the more final and catastrophic event, the Dissolution of the monasteries? Clearly modern historians are going to have to face that question much more squarely in the future. The 'bare ruined choirs' are places of great beauty and shrines of peace visited by thousands. Perhaps in a certain sense there was no 'death' of monasticism in the 16th and 17th centuries, and the spirit lived and lives.

Certainly today there is a new expectation of seeking God and the closer following of Christ. Roscrea Abbey in County Tipperary and the new Mellifont Abbey in County Louth are in existence. But the expectation is greater, for Christ is alive and there is a promise of a Springtime for Christianity.

The Cistercian Abbeys of Tipperary by Colmcille Ó. Conbhuidhe, O.C.S.O. ed. by Finbarr Donovan [Four Courts Press, Dublin, 1999, ISBN 1-85182-381-6]

\section{CHRIST CHURCH, DUBLIN}

\section{by Susan M. Parkes}

Christ Church Cathedral, situated in the centre of medieval Dublin, was founded as part of a religious house of the Augustinian Canons and at the Reformation was reconstituted as a secular cathedral. Therefore its history is one of major interest to historians of the city and recently the Cathedral Chapter in a praiseworthy effort have decided to publish a series of documents relating to the history of the cathedral. The series is edited by Dr. Raymond Gillespie and there are four volumes published to date, two of which are reviewed here.

The first of the series The Proctor's accounts of Peter Lewis, 156465 contains accounts of money spent on the upkeep of the cathedral building and its activities. The manuscript text is held in the library of Trinity College, Dublin and two modern transcripts have been made both of which have been used to produce this printed text. Peter Lewis came to Ireland in the retinue of Sir Anthony St. Leger who was appointed lord deputy in 1540 . He served as chaplain to St. Leger and then decided to stay in Ireland. His appointment as precentor of the newly reconstituted cathedral of Christ Church was due to the patronage of Sir Henry Sidney who became lord deputy in 1565.

Under the rules of the cathedral the proctor was elected annually from the members of the cathedral chapter and at the end of the period 
had to furnish accounts of his stewardship'. The proctor's accounts contain details of the expenditure of the cathedral on restoring and maintaining the building and on daily routine items required for the religious services. During Lewis's year of office the cathedral was in need of major repair as the south wall had collapsed, the crypt vault had been damaged and the nave still had no roof. Payments recorded in Lewis's accounts include those to masons, carpenters and heliers engaged in the repair as well as 'item paid to Mr Michell Pentony for this quyer of paper to make this book, the $\mathrm{x}$ day of October'. The items needed for the running of the cathedral included candles for the 'quer, the hellyers man and the workemen macking of morter, and for the massons super'; tallow for greasing the bell ropes; and money 'to Tady, helleyer hadysman to cleane the gutters of the Dean's chambyr for the great snow that fell this Chrystynmas and frost'. Despite the changes of the Reformation the structure of the cathedral services continued and the saints' days were observed as before-'Fryday 29 of December. Thomas Beckett's day. Spend in the quere in candlyght, in the quere and churche'. and 'Good Fryday, I paid for manchet and loffe bred for the vycars, to them by custome as they says of old tyme apon the house cost by the proctor for the yer being.'.

The other volume in the series entitled The Registers of the Christ Church Cathedral, Dublin includes the medieval book of obits, funeral entries form the proctor's accounts, 1542-1735, the first register of Christ Church, 1710-1848, and the second register, 1847-1900. The book of obits which was first published in 1844, contains the names of over 1,000 persons arranged in calendar order according to date of the commemoration of their death. Obituarial prayer was an important ritual in the medieval cathedral and wealthy persons gave donations and bequests to ensure prayer for their souls. The lists include the names of archbishops, abbots and priors as well as lay members of the congregation. The mayors of Dublin, anglo-norman lords and members of gentry families of the city are listed and include famous persons such as 'Strongbow', James Butler, earl of Ormond, and Garret More Fitzgerald, eighth earl of Kildare. In later centuries the cathedral became a 'favoured location' for the burials of English officials of government and for titled Irish families while the connection with the Fitzgerald family continued throughout the eighteenth century. The later registers list baptisms, marriages and burials and although the strong links between the civic community and cathedral weakened in the nineteenth century, the cathedral remained an important centre of worship and a historic feature of the city.

These two books are very well produced and each contains a concise introductory essay placing the documents in the historical context of the period. A full history of the cathedral is planned and this document series will provide valuable material for the history. Christ Church Cathedral was 'one of the largest and wealthiest corporate bodies in 
medieval and early modern Ireland' and its history provides a fascinating and detailed insight into the religious and social life of the capital city.

A History of Christ Church Cathedral, Dublin, documents series, No. 1.-The Proctor's accounts of Peter Lewis, ed. Raymond Gillespie [Four Courts Press, Dublin, 1996, ISBN 185182-218-6]; No. 4-The Registers of Christ Church Cathedral, Dublin, ed. Raymond Refausse with Colm Lennon [Four Courts Press, Dublin, 1998, ISBN 1-85182-344-1].

\section{TRENT IN IRELAND}

\section{by Thomas J. MORRISSEY, S.J.}

Much of the work of the synods 1600-1690 was concerned with bringing into effect the instructions of the Council of Trent, especially in relation to the celebration of the mass and the sacraments. The author's investigations disclose much about the pre-tridentine beliefs and practices of the people. This is not the least interesting part of the book. It will come as a surprise to some not familiar with the period that the priest offered mass behind a screen, and that although the element of sacrifice was accepted, the provincial Synod of Armagh, 1614 , felt it necessary to urge that the laity be instructed that the body and blood of Christ were offered in the Eucharist. Mass tended often to be seen as semi-magical, and the number of masses offered for one was deemed of central importance. The quantative approach was also applied to private prayers-so many Our Fathers and Hail Marys, so many rosaries, the number of times, on the Lough Derg pilgrimage, the pilgrim went around the chapel on his/her knees, and so on.

The author writes interestingly of Sin and Reconciliation, of Baptism, and of Marriage. Baptism was frequently by immersion, but the synods brought an end to this, particularly where young children were concerned because of fears for their health. The sacrament was often conducted in private houses in the closing years of the sixteenth century. This the author sees as an indication that Baptism was viewed 'as primarily a means of social regeneration and kin solidarity'. May it not rather suggest that there was persecution, few active priests, and that churches were not available? On Marriage there is an amount of material indicating the fluid nature of arrangements in pre-tridentine times. The ceremony was frequently arranged without the consent of the participants, and between children. Kinship purposes were a key factor. The ceremony was not infrequently conducted without a priest being present, particularly in disturbed times, cohabitation was widespread, the nature of the couple's commitment in marriage was in question, given the circumstances of the marriage and, linked to this, perhaps, was the easy tolerance of divorce. Marriage prior to 1612 was often held outside the door of the church, which suggested to the author that marriage was seen as a social process rather than as a solemn reli- 
gious rite. It may also suggest, perhaps, that, then as now, marriage was seen as both, rather than as one at the expense of the other.

The book underlines the desire mirrored in the synods to bring about uniformity of practice in the Irish church, and thereby bring it into line with post-tridentine churches in Europe. A factor in this were the religious orders. The author makes references to the early Jesuits in Ireland, but pays little or no attention to the friars who were far more plentiful in the country. Strangely, there is no reference to the impact of the Irish colleges on the continent, where the priests who returned to Ireland were imbued wth the teachings of the Council of Trent. These colleges, as a result, have been described, perhaps excessively, as the power-houses of the Counter-Reformation in Ireland.

The middle years of the seventeenth century were marked by the confederate wars and the puritan régime. By the 1660s, therefore, much of the earlier work was undone, and religious worship and parochial organisation were in a chaotic condition. The Williamite wars further disrupted recovery. By the $1690 \mathrm{~s}$, as a result, the Catholic reform in Ireland might be seen to have made little progress from the start of the century, particularly in the realms of doctrinal understanding, morality and superstition. Hence, as the author notes, 'a deep-rooted sense of Counter-Reformation morality had not been implanted in the minds of the laity and many of the clergy by the close of the century, despite the efforts of the synods and zealous ministers.' Nevertheless, 'outward piety and a sense of loyalty to the Catholic faith existed within the parish structure of observance', and there was reverence of the power of the sacraments and this rendered 'clerical authority and status... quite high by the closing decades of the century'. The emphasis on bringing practice into line with the Counter-Reformation church necessarily established a distance from the heretical beliefs associated with the Anglican church, and was in line with the contemporary neo-Thomist teaching on the separation of church and state.

The author's work is highly condensed, but repays application. It is a welcome addition to seventeenth century scholarship.

Catholic Synods in Ireland, 1600-1690 by Alison Forrestal [Four Courts Press, Dublin, 1998, ISBN 1-85182-410-3].

\section{A NEW LOOK AT THE CATHOLIC ELIZABETHANS}

\section{by FRANCIS EDWARDS, S.J.}

Lunn's verdict on his own work is fair. 'The book is aimed mainly at the general reader, though some students may find it a useful research tool' (p. vii). But one regrets that, apart from a general list of source books (pp. 253-70), there are no references to frequent and cogent passages quoted as illustration. The book is highly readable: indeed, with excursions into poetry and personal reminiscence it qualifies as 
belles-lettres as much as history. Refreshingly, it gets well away from the Good Queen Bess/Great Lord Burghley school. Eleven chapters cover key topics after a short prologue on the Henrician Reformation: the Elizabethan religious settlement, the arrival of Jesuits and seminary priests in the 1580 'invasion', the Armada, the Babington plot and Elizabeth Southwell's record of the dramatic death of the Queen.

The book is built round the interplay of several related families and their relations with the régime. The Arundells figure largest, Charles and Thomas, first Baron Arundell of Wardour. It becomes even more evident that Thomas Arundell deserves a biography. One is sorry that Lunn did not survive to write it since he shows intimate knowledge of the family history and of the period. The first baron was another lost hero of the time. Like most who got on the wrong side of the Cecils, or could not convince them that he was their servant, he failed in his day and has had a bad press ever since. He doubtless suffered from the process whereby records public and private were weeded to present the Cecils in the best light, and their rivals in the worst, as anyone who has researched in depth will know. This was easy since they both occupied key positions as secretaries of state and masters of the court of wards. The Earl of Oxford, also part of this story, was another who was never in the good books of the historians since he never got out of the bad books of the Cecils. Arundell, like Oxford, was dogged by ill-luck which easily looks like bad judgement. At times perhaps it was. But Oxford is getting serious attention especially from those who take him to be the 'real' Shakespeare. Arundell is still waiting. His relations with his conforming father, Sir Matthew, occupy chapter v. Sir Matthew, careful to keep in with government, especially touching religion, prospered if not exceedingly. Thomas pursued a way as independent as an Elizabethan could dare: and came to grief in consequence.

The years 1580 until 1595, the Jesuits' heyday, are not concealed as such. Campion receives very honourable mention. Persons is handled cautiously. 'Robert Persons, "his hands calloused by wire-pulling", in Rowse's bitchily memorable phrase, has come down to posterity as the cloak-and-dagger Jesuit whom everyone loves to hate, but the truth seldom pure and never simple, eludes us still' (pp. 64-5). Undeniably easier to handle are Robert Southwell and Nicholas Owen who were able, as Persons was not, to remain aloof from politics. Truth at its least pure and least simple lurks in the Ridolfi, Throckmorton and Babington plots which were used to bring Mary of Scotland to the block. Lunn skirts the first but says more on the latter two. Charles Arundell escaped abroad in 1583, after a court scandal involving Oxford, Francis Southwell and Henry Howard, to join a highly equivocal group of exiles. Lunn is just in his estimate of Gilbert Gifford but over-simplifies in saying that 'Mary' - in the bloody letter of July 17 1586-'approved of the plan'-to kill Elizabeth - 'and had not rejected the means to be used' (p. 155): likewise that Charles Paget and Thomas Morgan were 
'double traitors'. The problem with all such characters was that they had to pretend to be on the side of whoever they were talking to in order to find out what the other was up to. So it often becomes almost a matter of guesswork to decide whose side they were really on-apart from their own. Thomas Morgan, the most slippery of them all, advised Mary not to entangle herself with the Spaniards. This was wise for her though not welcome to the Hispanophils including Persons. It is sufficiently unlikely that Morgan would have betrayed Mary to her death since he was living on the income from her French dowry.

Finally we return to the contrasting careers of Baron Arundell of Wardour and Robert Dudley, illegitimate son of Douglass Sheffield and Robert, Earl of Leicester. Arundell after languishing in the cold finally managed to persuade Robert Cecil into giving him something to do. It was nothing less-or more-than to organise the run-down of the English regiment in Flanders. The hero of Gran received no adequate reward for this equivocal task successfully carried out. 'But Robert, having witnessed Ralegh's mis-trial and imprisonment, got out of England while the going was good, abandoning a debauched, corrupt court for one that was in every respect the opposite' (p. 232). So much the opposite that Ferdinand, Grand Duke of Tuscany, in recognition of his services, secured for him the titles of Duke of Northumberland and Earl of Warwick in the Holy Roman Empire. Perhaps Lunn was wise not to burden the book with scholarly apparatus. The way it is, more people will read it, and it will do them good. But I doubt if even scholars will know or remember all the facts produced.

The Catholic Elizabethans by David Lunn [Downside Abbey Press, 1998, ISBN 1-89866310-6].

\section{RECUSANCY AS DISSENT}

\section{by Rev. Stewart Foster}

Janet Gyford is an experienced local historian who has used the Essex town of Witham, on which she has already published a number of studies, to offer a sustained examination of religious dissent from the reign of Henry VIII to the end of the seventeenth century. Her structure is such that the early chapters of the book give not only an introduction to the history of the town itself, but also a clear guide to the chief tools by which she has conducted her research: wills and will preambles, ecclesiastical court records, court rolls. The author gives a balanced account of the recent debates in English Reformation studies (MacCulloch, Collinson, Haigh, Scarisbrick, Duffy), and on a local level, in a part of the country which embraced Protestantism more readily than many others-and this with particular reference to the revival of the cloth industry - one can detect the survival of Catholic practices and devotions until the very eve of the Cromwellian visita- 
tions: the last donation in Witham for a votive light to be kept burning in St. Nicholas's church was made by Thomas Smart in 1535. Such information and countless further pieces of supporting evidence drawn from the Essex Record Office, Public Record Office and other repositories, together with the generous use of maps and illustrations, make the book a very attractive source of reference even for those with a limited historical background.

This study makes a valuable contribution to the study of Catholic recusancy in mid-Essex, particularly by relating it to the wider canvas of dissent from the Established Church, anti-Catholicism and penal statutes, but also to the growth of tolerance between Witham townsfolk and their Catholic neighbours. The principal Catholic family was the Southcotts (Southcotes) who settled at Witham Place in 1563 and lived there for much of the next two centuries. John Southcott married Magdalen Waldegrave, the daughter of Sir Edward Waldegrave, a Marian Privy Councillor who died in the Tower in 1561 after he was accused of attending Mass, and sister to Lady Mary Petre (wife of the first Baron). Other Catholic families in Witham in the late sixteenth century were the Bayles, Ridgleys and Campions.

In the period before the Civil War there is less evidence of identifiable Catholic families other than the Southcotts. The Civil War itself witnessed a fresh outbreak of anti-Catholicism, with a series of attacks on Catholic property in Essex in 1642. The Southcotts were Royalists and Witham Place was raided in 1648. The returns for the Hearth Tax in 1673 show that Sir John Southcott made payment for eleven hearths, being the largest propertyholder in the town, and three years later Bishop Compton's survey found three adult Catholics in Witham, probably all members of the Southcott family. In 1687 the Catholic interlude under James II saw a priest visting the town. In the eighteenth century Witham Place became the chief Catholic centre in mid-Essex, although not on the scale of its Petre neighbours to the south-west (Ingatestone Hall and Thorndon Park). To complete the story, Witham Place was served by both Benedictines and Jesuits in the eighteenth century, the house being the precursor to the establishment of a recognisable mission (dated to 1774), with the church of the Holy Family opened by Dr. Tavares, a Portuguese secular priest, in 1851. In 1989 the redundant Anglican church of All Saints was obtained by the Diocese of Brentwood to serve as a Catholic church. This book is to be recommended as a model of its genre, making the history of religious affiliations in a particular Essex market town accessible to a broad readership.

Public Spirit: Dissent in Witham and Essex $1500-1700$ by Janet Gyford (available from the author at Blanfred, Chalks Road, Witham, Essex, CM8 2BT, 1999, ISBN 094643403 4, £13.50). 


\section{THE SURVIVAL AND DEVELOPMENT OF CATHOLICISM 'NORTH OF THE SANDS'}

\section{by MAURICE WhiteHEAD}

Writing in 1825, Edward Baines, author of the first directory and gazetteer to cover the whole Palatinate of Lancashire, noted that the portion of Lancashire north of the sands of Morecambe Bay "notwithstanding its many recommendations... labours under the disadvantage of an ineligible, and somewhat dangerous communication, both with the south-east part of this county, and with the county of Cumberland to the west'. Hitherto, it has been generally assumed that the geographical isolation of the Furness peninsula before the coming of the railways was responsible for the dying out of Catholicism in that region until the immigration of Irish labour in the nineteenth century.

Anne Parkinson's new study of Catholicism in the area over an 870year period, from 1127 to 1997, proves how erroneous this assumption has been. It recounts the vitality of pre-Reformation religious life in the region, even if this was accompanied by strife and factionalism in the Cistercian community of Furness Abbey on the eve of the Dissolution; the use made of the isolated coast of the peninsula by 'seminary priests and papists' as a means of passage into Scotland and the Isle of Man; and the struggle of the two gentry families, the Prestons and the Kirkbys, in leading a largely plebeian Catholic population in the early Stuart period.

If Catholicism in north Lancashire reached its nadir in the aftermath of 1688 , and became reliant during the first half of the eighteenth century on the services of 'riding' priests, covering the Kendal, Workington and Furness districts, there was a gradual improvement in the fortunes of the Catholic community following the arrival of the Scots antiquary and historian, Fr. Thomas West, S.J., about 1765. His example, in establishing cordial relations with the local nobility, gentry and Anglican clergy, was to lay the foundations for the future development of ecumenism in the region.

With the advent of the industrial revolution and the coming of the railways, the centre of gravity of Catholicism shifted from Dalton-inFurness, the capital of the peninsula and the traditional centre of recusancy, to Barrow. The subsequent history of the Catholicism of the area, while largely a vignette of similar developments in other English industrial towns, is distinctive: unlike some other areas, the influx of a large immigrant Irish population did not lead to increasing sectarianism, but rather to a further growth of ecumenical good relations that endure to the present day.

A major strength of the entire work is the way in which the regional dimension is linked, chapter by chapter, to the wider national context. Published by the Centre for North-West Regional Studies at the University of Lancaster, this monograph is the thirty-seventh in a series 
that began in the mid-1970s and that has included a number of other monographs on aspects of recusancy. It is a welcome addition to that series, is well produced, but, at 114 pages, would have benefited from the inclusion of an index.

A History of Catholicism in the Furness Peninsula, 1127-1997, by Anne C. Parkinson [University of Lancaster, Centre for North-West Regional Studies, 1998. ISBN 1-86220055-6.]

\section{PERSONS REDIVIVUS}

\section{by VICTOR HOULISTON}

Readers of Recusant History will need no persuading that Robert Persons is a subject worthy of note. Michael L. Carrafiello;s monograph, a 'political biography' that challenges what the author calls 'the present historiography of English Catholicism based exclusively on the heroic image of martyrs like Campion' (p. 11) is therefore to be welcomed as a contribution to the debate, if only because it so clearly indicates how much still needs to be done.

A book which in all innocence uses on its cover a portrait known for over ninety years not to be of Persons, and chooses without explanation the spelling of his name that most specialists have abandoned, is not promising. However, there is much of value. Carrafiello provides the most thorough analysis to date of some of Persons's key political writings, including those on equivocation which followed the Gunpowder Plot. His comparison of the ideas of the Conference about the Next Succession with those of Francesco Suarez is particularly illuminating, and he hits the right note in his assessment of the Memorial for the Reformation of England:

...the Memorial is the quintessential Parsons: theological and religious in scope and origin, temporal and practical in specifics. His central contention, that the prince's arrogation of ecclesiastical power had created a depraved and miserable heretical kingdom, is at once both simple and overpowering. Parsons had an equally arresting solution. His reformation would reach into all aspects of Englishmen's lives and thereby establish a Christian commonwealth worthy of the apostles. (p. 87).

Carrafiello concentrates on the political activism that he feels has been 'downplayed' by the Jesuit historians Thomas McCoog and Francis Edwards. His thesis is that even from the beginning of the English Mission in 1580 Person's overriding aim was the toppling of the Elizabethan régime, if possible with the support of James VI of Scotland, and he goes on to declare, memorably if wildly, that Person's writings provided 'ample ideological ammunition to set off the actual big bang that Fawkes and company planned' (p. 117). The wider argument, which is based on inferences drawn from ambiguous references in Person's correspondence, is advanced to break the much-publicized 
'deadlock' between Christopher Haigh and John Bossy over the impact and significance of the Jesuit Mission to England. If the political agenda can be shown to have dominated Persons's thinking from start to finish, this would clarify the question of Jesuit pastoral methods, and also render redundant the rather tortuous efforts of Peter Holmes to divide Persons's career into alternating periods of pacifism and rebellion. The critique of Holmes is well-founded. But the researches of Albert Loomie, Bossy and McCoog suggest that the truth is not less but more complex than Holmes believed. Persons's ultimate objective was always the renewal of Catholicism as England's national religion; the varied means to this-pastoral, educational, political, ecclesiastical-preoccupied him variously as circumstances changed.

The chief failure of this monograph is its extraordinary omissions. To read it, you would scarcely be conscious of Persons's work in founding seminaries or his authorship of the Christian Directory. You would be left in the dark about the Jesuit General Aquaviva's attempts to wean Persons from political involvement to 'our way of proceeding', something to which McCoog has given much attention. References to such major writings as the Philopater, the Treatise of Three Conversions of England, the Warn-word to Sir Francis Hastinges Wast-word, and the Judgment of a Catholike English-man are minimal, second-hand or nonexistent. According to the bibliography, Carrafiello has read or consulted only twelve of Persons's more than thirty printed works, and his analysis of this reduced corpus is restricted to the content, ignoring the polemical strategies which made the books so effective. Even a political biography written by an historian needs to be much more firmly grounded in Persons's literary output.

There are also several factual shortcomings. It has never been conclusively demonstrated that Persons wrote either Leicester's Commonwealth or the Conference about the Next Succession, yet Carrafiello treats them as entirely Persons's work without so much as a glance at the authorship question. On the authority of Taunton (1901) he asserts that Persons was taught by Suarez during his Jesuit training in Rome (pp. 16, 51), whereas Suarez arrived in Rome at almost the same time that Persons left for the English Mission in 1580. He mistakes a description by William Clarke of the Conference for the Memorial ( $\mathrm{p}$. 75) and gives the date of Persons's intervention in the English College, Rome, as 1596 instead of 1597 (p. 91). These errors are of varying gravity, but they confirm one's doubts about the author's mastery of his subject.

Robert Parsons and English Catholicism, $1580-1610$ by Michael L. Carrafiello [Selinsgrove: Susquehanna University Press/London: Associated University Presses, 1998, ISBN 1575910128$]$ 


\section{RECUSANTS ABROAD}

\section{by LEO GoOCH}

In November 1773 the Gazzetta Toscana reported that 'GodCavaliere Inglese' had arrived in Florence. The English visitors already knew the deity's nationality, of course, but at the same time they must have wished that the editor would just pay attention and get their names right a little more often, especially as so many thousands of them, including a large number of Catholics, had passed through the city over the years.

There were three periods during the century when Europe was at peace and when travel to Italy could be undertaken safely: 1713-33, 1748-56 and 1763-97; and there were many different reasons for going there. Eleanor Glanville told her widowed sister-in-law: 'you may live far better [in Rome] than in England' and, despite what her correspondent might have feared, 'as for your religion there is nobody will force you to change, for ye citty of Rome is like ye Citty of London or Bristol. Here is all religions in it'. The consumptive Laurence Sterne decided to 'saunter philosophically for a year or two' in Italy for his health; he hoped to add ten years to his life but he died within two years of his return home. Some were sent there to round off their education (a number of young Catholics spent a term at Turin Academy where the priest-scientist John Turberville Needham taught in the 1760s), to acquire the social graces and extend their cultural horizons, not that all of them appreciated the opportunity: after a fortnight in Rome in 1787, George Heneage complained that he had 'found no entertainment' to suit him, and opera was Richard Shuttleworth's only diversion.

For English Catholics, an Italian tour was essentially a pilgrimage to Rome, and they were usually well-received; many went during the Holy Year of 1750. They would attend services in St. Peter's, visit the English College and obtain a papal audience. For the latter, the good offices of the Scottish Jesuit priest Peter Grant were advantageous. Grant lived in Rome from 1726 to 1784 and became something of an institution, though he was inclined to reserve his best favours for the more distinguished British travellers. He was indulged by Pope Clement XIV but Pius VI (who, it seems, was so proud of his ankles that he wore his gown short to show them off) was not so fond of him. Once when Grant presented Sir Thomas Gascoigne and Henry Swinburne at a private audience, Grant 'talked so much that the pope [Pius] could not get in a word'. His fellow-Jesuit John Thorpe remarked that Grant certainly did not die 'by any excess of ecclesiastical rigour'.

The presence of the Stuart court in Rome, was a source of social and diplomatic anxiety for most British visitors. Lord Chesterfield advised his son never to meet a Stuart at all if he could help it. The titular king and his two sons, however, were counted among the sights of Rome 
and were a constant source of interest, but the British were obliged to gawp from a distance and avoid the Palazzo Muti (which displayed the royal arms above the main door and was guarded by papal soldiers) so as not to give 'umbrage at home', as the eighth Duke of Norfolk put it, for everyone knew that Hanoverian secret agents were based in the city. Doubtless they also thought it prudent to steer clear of such fanatics as Charles Radcliffe, 'ye fiercest Jacobite alive', whose parties frequently gave rise to 'desordres parmi la jeunesse de Rome', and who was threatened with expulsion by the Pope. Actually, the English tourists were generally well-behaved and did not succumb to vice as was commonly thought at home. There were, however, the occasional embarrasssing incidents. Sir Thomas Gascoigne had to bribe witnesses to keep silent about his shooting of a coachman. The Jesuit Charles Booth was dismissed as Rector and expelled from Rome for welcoming Charles Stuart to the Venerabile; Booth once felled the papal Maestro de Camera 'with a great English pudding', but the Italian's offence is not stated.

Few leading English intellectuals of the first half of the century visited Italy; neither Hogarth or Vanbrugh went, nor did Pope, Defoe, Swift or Fielding, though whether they were xenophobes, intellectual snobs or just reluctant to face the rigours of the journey is unclear. But the next generation was more inclined to venture south. Boswell, Garrick, Gibbon, Smollett, Sterne and Wilkes were all in Rome for the winter seasons of 1763-5. The irascible, churlish and narrow-minded Smollet, however, quite missed the point of the whole thing. He thought it odd that the moment the English set foot in Italy they were 'seized with the ambition of becoming connoisseurs in painting, musick, statuary, and architecture', but that, of course, was precisely the reason so many of them went there, and why some went back several times. These were the scholarly tourists intent on the study of Classical and Renaissance culture. They would learn Italian, undertake a course of art-studies, buy sculptures and pictures, commission works of art and sit for their portraits. Smollett also remarked that the Italians did 'not fail to flatter this weakness for their own advantage'. Well, serve the tourists right if, like him, they relied on guide-books and were too mean to engage an antiquary to advise them. But then, it was a comparatively simple matter to swindle Protestants because they were gullible and felt much less at ease in Italy than the Catholic gentry who were more at home and, frankly, rather more cultivated and discriminating. In any case, the British Catholics called on resident experts to advise them, especially the Scot James Byres (in Rome 1758-90) and the English Jesuit John Thorpe (in Rome 1756-1792). The important collections of Henry Blundell of Ince Blundell, William Constable of Burton Constable and Lord Henry Arundell (VIII) of Wardour among many others owed a great deal to the recommendations and agency of Byres and Thorpe, and they both receive extended treatment in this dictionary. 
Contact with the Italians was kept to a minimum; John Giffard had no great opinion of 'the modern Romans' and Richard Shuttleworth said Rome would be insupportable without the English, 'for the natives are so damned formal there is no bearing them'. Smollett thought Italian women 'the most haughty, insolent, capricious and revengeful females on the face of the earth'. It was fortunate, then, one supposes, that the visitors had art to interest them, and it was presumably their insularity which led to the creation of a dedicated infrastructure for their tours. John Collins kept a public house on the Strada Ghibellina in Florence for his fellow-countrymen; it was generally full though 'not the most reasonable'. The Englishwoman Mrs. Vannini's inn on the Piazza Soderini was much frequented, and a Mr. Hadfield kept a hotel furnished in the English manner. 'Kennet's, a very good English publick house' flourished in Venice. In Rome there was the English Coffee House on the Piazza de Spagna where most English visitors gathered in the evenings. Thus the social, residential and art-historical requirements of the tourists were kept firmly in British hands. There was no need even to involve the Italians in the despatch of portraits and other art-objects to England, for the English Catholic merchants and shippers Joseph Denham and Peter Diharce were well-established in Leghorn and Civitavecchia.

This dictionary is not just a major contribution to the literature of the Grand Tour, it is an important source for the study of the cultural history of the eighteenth-century recusants, for hardly an English Catholic gentry family is absent from its pages. Despite one or two errors about Catholic practice, its scholarship is impressive. The bibliography deserves attention; it occupies seventeen pages of small print and is largely a list of manuscript collections, which many researchers will find of inestimable value. Apart from its scholarly purpose, however, the dictionary affords general, serendipitous pleasure. It is probably of no particular consequence to find that Sir Thomas Dereham refused to contemplate marriage lest his Catholic and Jacobite loyalties be 'endangered by his posterity', or to discover that around 1760 Mr. Martin, an Irish Catholic, introduced the potato into Savoy, or even to learn that Emma Hamilton was captivated by the beauty of the twenty-one-year-old eligible Catholic bachelor Henry Swinburne (and what a historical might-have-been that conjures up), but it is such engaging details that make this biographical dictionary such a delight to use.

A Dictionary of British and Irish Travellers in Italy 1701-1800, compiled from the Brinsley Ford Archive by John Ingamells, [Yale, 1997. ISBN 030007-165-5]. 


\section{AN EIGHTEENTH-CENTURY CATHOLIC MUSICIAN}

\section{by Philip Olleson}

John Baptist Grano (c.1692-c.1748) was an English Catholic trumpeter, flautist and composer. His parents were Johon Baptist Grano and Jane (née Villeneuve), originally from Brabant and Picardy, who owned a haberdashery shop in Pall Mall. His younger brother Lewis was also a trumpeter and flautist; his sister Mary married James Butler, and among their children was the eminent Catholic lawyer Charles Butler.

Grano's musical career seems to have begun around 1714, when he first appears in concert advertisements in London newspapers as a trumpeter and flautist. In 1720, he was a member of Handel's opera orchestra at the beginning of the operatic venture known as the Royal Academy of Music. This appears to have been the extent of his connection with Handel, and so the description of him as 'Handel's trumpeter' may be thought to overstate the case more than a little. On both of his instruments he was evidently a player of some distinction: on hearing him play the flute in 1725 the poet John Byrom declared that he was 'the only man for it', and the music historian John Hawkins recorded in his History (1776) that he had been 'a celebrated performer' on the trumpet. Amongst his compositions were six Solos for a German Flute, a Hoboy or Violin, published by Walsh in 1720, and a number of songs.

Grano's diary (Bodleian Library, Rawlinson D34), an abridged transcript of which forms the basis of this handsomely produced volume, covers the period between May 1728 and September 1729, when he was imprisoned for debt in the Marshalsea Prison. This was a time when the Marshalsea and other prisons were coming under intense scrutiny. In February 1729 a parliamentary committee of enquiry into conditions in prisons had been set up. It visited the Marshalsea a month later, and the resulting report is a rich source of information on the prison and its inmates during Grano's time there. In addition, in August 1729 William Acton, the chief turnkey, went on trial for the murder of four inmates under his charge; he was acquitted, but the account of his trial is similarly revealing of conditions in the prison at the time.

But the diary does more than chronicle Grano's experiences inside the Marshalsea and the idiosyncrasies of that grim institution. For much of the period of his imprisonment, Grano was able to leave the prison by day to pursue his business and to try to extricate himself from his financial difficulties. The diary records his activities outside the prison as a professional musician, appearing at informal music societies in inns, organizing concerts, and teaching.

There is comparatively little in the diary of specifically Catholic interest. During Grano's time in the Marshalsea, his mother used the services of the Jesuit priest Jean Lallart (see C.R.S. vol. 13, Miscellanea viii, 172) to keep in contact with him, and the diary records a number of Lallart's visits. There are also a number of passing refer- 
ences, none of them particularly detailed or informative, to Grano's attendance at Mass and Vespers at the French, Sardinian and Portuguese embassy chapels.

As John Ginger readily admits, Grano was not a profound writer, and one looks in vain in the diary for much comment on his own state, or indeed anything more than a fairly bald chronicle of his everyday doings both inside and outside the Marshalsea. In this respect, as Ginger points out, Grano as a diarist is closer to Pepys than he is to the more reflective Boswell. Like Pepys, Grano is disappointing as a commentator on character or as a setter of the scene, and we need to piece together his world from a series of fragmentary remarks scattered through the diary, rather than from extended passages of description.

Preparing an edition of such a diary presents great problems to the editor. Without commentary or annotation, many passages in the diary would be incomprehesible to the average reader, and the whole would be of little interest except as a curiosity. What the editor must do is to find some way to explain the general background and context, and in addition to comment on any passages which would otherwise remain obscure. Ginger has faced this problem head-on, and his solution is entirely successful. Rather than providing detailed annotations to the diary itself, he divides it into nine sections, following each with a commentary which sets the necessary background, fleshes out Grano's narrative, and highlights passages of particular significance and interest. This is augmented by an introduction to set the initial scene, an appendix listing the dramatis personae of the diary, a comprehensive bibliography, and an index. Ginger's researches in both manuscript and printed material have been particularly assiduous and comprehensive, and as a result he has been able to provide more detail on the background to Grano and his circle than one might have thought possible. The end-product is by no means an easy read, but it is a rewarding one for those prepared to perservere with the necessary cross-referencing between diary text, commentary, and list of dramatis personae.

Handel's Trumpeter: The Diary of John Grano, ed. by John Ginger [Bucina: The Historic Brass Society Series No. 3, Pendragon Press, Stuyvesant, New York, 1998, ISBN 0945193-96-3].

\section{RADICAL MEN AND WOMEN}

\section{by V. Alan McClelland}

In contemplating the human condition, D. H. Lawrence denied he was 'a soul, or a body, or a mind, or an intelligence, or a brain, or a nervous system, or a bunch of glands, or any of the rest of these bits of $m e$ ', for 'the whole is greater than the part' and, hence 'I, who am man alive, am greater than my soul, or spirit, or body, or mind or consciousness, or anything else that is merely a part of me. I am a man and 
alive.'In this statement, Lawrence is protesting about the tendency in literary criticism to consider than man can be analysed and evaluated in relation to only part of his being. Lawrence was for 'thorough' and he was content to make the essential point that men and women are organic and spiritual entities. A disservice is done to them if there is a failure to recognise their fundamental integrity.

The virtue of all four books considered here is that they attempt, each in its own way, to adopt this concept of unity, whether the central theme is, with Diane Watt, one of mystical experience or, as in Gerard Moran's book, political and social commitment is at issue or, as in the work of Aidan Nichols and that of Madeleine Beard, the essence lies in inner awareness of a deep spiritual mission or human destiny that lies at the core of faith itself and its sense of mission.

Diane Watt in her analysis of women prophets in late medieval and early modern England concentrates upon the lives of four women who exerted a remarkable influence in their generation-Margery Kempe, Elizabeth Barton, Anne Askew and Eleanor Davies. In considering her subjects' fragility, she is able to indicate their important rôle in the story of women's visionary knowledge, concentrating upon their commitment to the search for greater understanding of the love of God that lies at the centre of all mystical experience. The quest enhanced their vulnerability in the face of authority in Church and/or State. Diane Watt sees, in the posthumous experiences of these women, examples of what Germaine Greer considers in our own day to be the transience of female fame. Watt's book is a powerful contribution in the general field of women's studies for the new light it casts upon the tradition and perception of female prophecy.

To a certain degree Aidan Nichols' study of seven Dominican friars who were active in England in the years between 1930 and the Second Vatican Council, can be placed in the same genre as the study by Diane Watt. In recommending the volume, the Dominican Master General, Timothy Radcliffe, regards each of the delineated friars as showing the common conviction that all theology is ultimately mystical, portraying ' $a$ mind in love' with God. Considering the intellectual impact of Victor White, Gerald Vann, Thomas Gilby, Sebastian Bullough, Gervase Mathew, Kenelm Foster and Conrad Pelper, Father Nichols emphasizes the unity permeating pastoral responsibility and ascetical/mystical experience that enabled the friars, through the medium of Aquinas, to see faith 'as a light', a source of illumination that admitted, in the words quoted from Crashaw, 'great drafts of intellectual day'. Nichols presents the ability to see the developments of life, in the intellectual, cultural and physical spheres, as a totality sub specie aeternitatis, as the essence of the Christian tradition.

It is the vision of such a concept of unity and other-worldliness that constituted the driving-force, which attracted by the teaching authority of an infallible Church, inspired the spiritual journey of many of the 
nineteenth-century converts who are considered by Madeleine Beard in Faith and Fortune. In her study of conversions, she sees this vision as intrinsic to the nature of Roman Catholicism-'the belief that one cannot disentangle the physical from the spiritual'. It is the lack of strength, indeed, of such a concept in the representatives of the Church and of a notionally Christian society that have often given rise to prophets and reformers (many eventually canonised), impelled by a burning desire for spiritual renewal and regeneration. Gerard Moran's collection of essays on selected Irish radical priests in the period 1660 to 1970 , for instance, is a fascinating study of clerics who came into conflict with State and/or Church, often on political and social issues, when they considered their 'practical' approaches to the expression of Christianity were being compromised. Although none of the priests he presents can be described as a theological radical, each certainly believed profoundly in the inspiration of the Christian tenets and beliefs to which he had early given allegiance.

Secretaries of God by Diane Watt (D. S. Brewer, Cambridge, 1997, ISBN 0855991524 7)

Dominican Gallery: Portrait of a Culture by Aidan Nichols (Gracewing, Leominster, 1997, ISBN 085244393 5)

Radical Irish Priests 1660-1970 ed. Gerard Moran (Four Courts Press, Dublin, 1998, ISBN 1-85182-249-6)

Faith and Fortune by Madeleine Beard (Gracewing, Leominster, 1997, ISBN 085244392 7)

\section{AN EPISCOPAL ATHANASIUS}

\section{by Rev. James Pereiro}

Chesterton felt that the most important event in English history during the eighteenth century happened in France: the Revolution. In a similar vein, it might be suggested that the event most influential in the life of the English Catholic Church during the first half of the nineteenth century took place in Ireland.

The struggle for Catholic Emancipation in England in the first two decades of the century presents a quaint picture: a small group of refined gentlemen, mostly from the stock of the old Catholic landed gentry, carefully weighing wordings for oaths of allegiance to the sovereign, under the vigilant eyes of Vicars Apostolic who largely suspected in them a readiness to compromise doctrine for the sake of social position. The Irish bishops seemed almost relegated to the rôle of a Trade Union block vote at a Labour Party conference, to be cast by Bishop Milner. The picture changed dramatically in the 1820s. The old Catholic English gentry and the English bishops, the carefully and 
laboriously crafted oaths and guarantees, were all swept aside by winds then blowing from the neighbouring island.

The two books here reviewed are an exceptional contribution to our knowledge of events in Ireland in the third decade of the nineteenth century. As might be expected, Politics, Interdenominational Relations and Education is of greater interest to the student of English history, and it is essential reading for anyone interested in the period. Its four chapters deal with: Catholic Emancipation; the consequent efforts at Repeal and Reform; interdenominational relations; and education. This study of Bishop James Doyle, Bishop of Kildare and Leighlin from 1819 to 1834 , offers a privileged observation point from which to survey the Irish scene. Doyle was at the centre of the debate on those questions, and soon became the dominant voice within an Irish episcopate which at this time showed a greater independence from the English bishops that had previously been the case. Doyle wrote most of the Irish hierarchy's collective documents on key subjects. Besides his own personal writings and his depositions to successive Parliamentary Committees of Inquiry, he made his voice one to which politicians and members of the public on both sides of the Irish Sea listened attentively.

McGrath examines in detail Doyle's deeply felt sense of hurt at the condition of Irish Catholics, and his continuous efforts to ameliorate it. His approach underwent a significant change of emphasis around 1823. Doyle's early insistence on the duty of Catholics to give allegiance to constituted temporal power gave way to greater emphasis on the legal and constitutional right of subjects to agitate for redress of grievances, but he always condemned violence. The remonstrances of the Bishop and his clergy did much to calm the tense atmosphere of the times, but did not quell all agrarian violence in his diocese.

The founding of the Catholic Association by O'Connell (1823) proved a new, and this time definitive, stage in the struggle for Catholic Emancipation. Doyle's association with, and sincere support for, O'Connell's campaign for Emancipation was not, however, uncritical. In later years there were open differences between them over O'Connell's post-Emancipation agitation for Repeal of the Union and his Poor Law proposals. Doyle, although theoretically in favour of Repeal, was opposed to concentrating all energies on trying to attain it. He judged this a tactical mistake: it was destined to failure, and diverted Catholic energies from attempting to obtain favourable legislative reforms within the new circumstances created by Emancipation. In later years he came also to regret the stranglehold which O'Connell had over Irish politics, perceiving it as proof of Irish unreadiness for self-government.

The 1820s also witnessed the start of the 'New Reformation', a Protestant crusade to effect the conversion of Ireland to Protestantism. The Protestant Archbishop of Dublin could declare: 'In truth, with respect to Ireland, the Reformation may, strictly speaking, be said only 
now to have begun.' The 'New Reformation' may not have made many converts, but it certainly produced a renewal of interdenominational polemical literature. Doyle was to play a very important rôle in it, and, in the midst of the debate, he put forward his ill-defined and highly controversial proposals for reunion. Nothing much came out of it. Renewed religious tensions, however, brought the question of National Education to the fore.

At the time, the Kildare Place Society, the most important of the Irish educational societies, was the recipient of the whole government grant for education. Although under Protestant control, it professed nonsectarianism, rejected proselytizing, and, following those principles, insisted on simple reading of the Bible, without notes or commentaries. For this last reason, it had been the object of Catholic criticism. The fresh proselytizing efforts of the 'New Reformation', led the Catholic bishops to look at the Kildare Place Society with even greater suspicion. Bishop Doyle's rôle in its dismissal, and in the consequent setting up of the Irish System of National Education was paramount. His attacks on the principle of Bible education without notes or commentary, and his success in removing Catholic children from the Society's schools, while trying to build Catholic ones for them, made it plain to the government that a National System of Education on the lines of the KPS could not work. Doyle propounded interdenominational education. Catholics and Protestants were to attend school together, while receiving religious instruction separately from ministers of their own faiths. This plan did not work in practice. The setting up of the Board of Education in Ireland in 1831 did not fulfil all the aspirations of the Catholic Church but created de facto a system of education favourable to Catholics.

The effects of the Irish debate on education were to be felt in this country. Ireland served as a testing ground for policies and personalities who-like Spring-Rice or T. Wyse-were to loom large in the educational question in England in the late 1830s and early 1840s. A generation of parliamentarians became familiar with the subject during the debates which led to the setting up of the Irish System of National Education.

The author confesses in one of the prefaces that he "has assumed a certain familiarity on the part of his readership with the basic issues and has been concerned to make extensive use of the primary sources.' It is perhaps the duty of a reviewer to remark that the author seems to assume too much on certain points, and that, at times, the clear unfolding of a sequence of events is almost lost in an overgrowth of detail. Again, the criterion used to order the subject matter-with individual topics partially treated in different chapters-adds in certain instances some inconvenience for the reader. These are minor criticisms. McGrath has grappled successfully with an eventful time, rich in docu- 
mentary evidence, and we should be grateful for his achievement in presenting a vivid and complete picture of it.

Religious Renewal and Reform in the Pastoral Ministry of Bishop James Doyle of Kildare and Leighlin, 1786-1834, by T. McGrath [Dublin, Four Courts Press, 1999, ISBN 1-85182371-9]; Politics, Interdenominational Relations and Education in the Public Ministry of Bishop James Doyle of Kildare and Leighlin, 1786-1834, by T. McGrath [Dublin, Four Courts Press, 1999, ISBN 1-85182-372-7].

\section{AN IDEOLOGICAL BATTLEGROUND}

\section{by REv. David J. OAKLEY}

This important study of the Wesleyan elementary schools project will appeal to scholars from a number of fields. Those concerned with education, and particularly those who care about denominational schools, will find a well-documented and researched examination of the early battles between government and the churches. Ecumenists, who are interested in the historical background of their movement, will encounter a reminder of a more polemical and suspicious age. Pastoral theologians, who want to examine the relationship between theological reflection and society, will discover a wealth of information about a century with many rich seams still awaiting the miner's pick. Political scientists, who seek the liberal atmosphere of post-Enlightenment secularism, will read of an ideological battleground. This struggle is a salutary lesson of what happens if politicians attempt to disregard the influence and interests of the Christian communities.

Smith has amassed an impressive amount of detail from extant source materials. He has chosen to present the story of nineteenth century Methodism and its involvement in education, from the perspective of one dedicated campaigner, Dr James Harrison Rigg. The portrait of this formidable minister and educationalist is presented in a lively and engaging manner. Rigg was imbued with the principles of a Wesleyan mindset. His fundamental beliefs were the inspiration for his tireless work in the field of education. Rigg was elected President of the Methodist Conference on two occasions. He chaired his denomination's education committee for many years. He was acquainted with leading churchmen and politicians of his time. and yet, there was something of the prophet in the man. He knew rejection and experienced defeat, especially towards the end of his ministry. Many of his colleagues were suspicious of his openness towards the leaders of other denominations. They did not have Rigg's insight and breadth of mind. In the end, their catalogue of mistaken policies and disastrous political decisions heralded the decline of Methodist involvement in education.

This monograph begins with the insight of John Wesley. The founder of Methodism wrote that 'if the Methodists were not a reading people the work of grace would die out in a generation.' (p.1) This insight 
provided the inspiration for his disciples' involvement in the building of schools and the provision of teachers to staff them. The 1850's witnessed an organised opposition to religious education among some parties. This was a threat to all denominational schools. Some Methodists, William Arthur for example, wanted to abolish denominational schools and replace them with state schools. The rising spirit of Rationalism steadied the rocking boat for a while. However, Methodism faced decline in hundreds of villages. A village day-school may have saved the chapels from extinction. When the Conference Special Committee met on 25 January 1891, Rigg was outvoted for the first time on educational matters. In effect, this was the end of Wesleyan denominational schools. Rigg had sought involvement with school boards and political lobbying when education legislation was before Parliament. This work, for the most part, was tedious in nature. Some members of the Methodist Conference thought the work was inappropriate for a minister of the Gospel.

Unfortunately, the Methodist machinery was not able to receive the necessary oil of ecumenical co-operation. Many ministers were fearful of 'Popery' and 'High Churchman'. Indeed, 'Popery was a mighty evil', only surpassed by the greater evil of infidelity. There was also a critical attitude towards a Church of England that was beginning to experience the full effects of the Oxford Movement. Fear and hostility were the hallmarks of a narrow denominationalism. Smith paints the picture of a truly 'Protestant' nineteenth century Methodism, defined by its opposition to others rather than its ability to work with other churches for a greater good. Rigg was not entirely of this mould. He worked on educational matters with Canon Gregory from the Church of England and Cardinal Manning, the Archbishop of Westminster. Indeed, Rigg's open attitude towards Manning, and certain correspondence with him, was the cause of much misunderstanding and mistrust of Rigg towards the end of his ministry. Smith's treatment of these ecumenical relationships is sympathetic and fair. There is still the need for a more detailed comparison between nineteenth century Methodist and Roman Catholic involvement in education. Smith's second comparative statistical appendix is a narrative waiting to be told!

The story of Dr. J. H. Rigg is worth the telling. He was a man of his age and subject to the harsh disciplinary attitudes of Victorian England. His passion for Methodism could sometimes blind him to the developments and grace-inspired events taking place around him. There are indications that Rigg was able to rise above these limitations and see something of the broader picture. His Christianity was concerned with the fundamental educational needs of the children in his society. $\mathrm{He}$ expended enormous energy in the pursuit of this concern and the practical application of his beliefs. His understanding of pastoral ministry was not limited to the narrow perspective of a fundamentalist position. Neither was he afraid to enter the market place of political debate and 
social policy building. Indeed, Smith's study of nineteenth century Methodism and Education is pertinent to those who are involved in this same work at the beginning of a new Millennium. There is much to be learnt from the witness and example, the mistakes and the reserve of those who have gone before us.

Methodism and Education 1849-1902: J. H. Rigg, Romanism, and Wesleyan Schools, by John T. Smith [Clarendon Press, Oxford, 1998, ISBN 0-19-826964-1].

\section{THE MIND OF MANNING}

\section{by MaURice WhiteheAd}

The past fifteen years have witnessed a spate of publications on the life and work of Henry Edward, Cardinal Manning, building on the pioneering work of Alan McClelland's 1962 study of Manning's public life and influence in the period 1865-1892. These include Robert Gray's 1985 biography of Manning; David Newsome's The Convert Cardinals: John Henry Newman and Henry Edward Manning (1993); a volume of essays entitled By Whose Authority?: Newman, Manning and the 'Magisterium', edited by Alan McClelland (1996); and Peter Erb's A Question of Sovereignty: The Politics of Manning's Conversion (1996). Taken together with the special issue of Recusant History in 1992, to mark the centenary of Manning's death, these studies have contributed greatly to our appreciation of a previously much misunderstood leader of the Catholic community in England and Wales.

Fr James Pereiro's latest addition to this growing literature fills an important void by tracing Manning's intellectual development from his days as the Anglican Vicar of Lavington in the 1830s to his rôle as Cardinal Archbishop of Westminster at the first Vatican Council in 1870. The study is the result of wide-ranging and ground-breaking research undertaken in Manning's surviving papers in Britain and at Pitts Theology Library at Emory University, Atlanta, as well as in related papers in Rome. The author is careful to focus on those aspects of Manning's life that have not previously received attention. This rationale explains both the scope and the terminus ad quem of the book. While there is considerable discussion of Manning's ideas on higher education, for example, his ideas on and work in developing schools, especially for the poor, as well as his thinking on social justice, both explored by earlier writers, are expressly not re-examined.

Strikingly, Manning's intellectual development is depicted as a continuum, moving gradually but inexorably from an Anglican to a Roman Catholic position as well as from the private to the public sphere. The author demonstrates how the peace and tranquillity of his years at Lavington allowed Manning the time and space to ponder deeply on theological matters in the privacy and intimacy of his study. Those early, intensely private foundations provided the bedrock on which 
Manning's highly public interventions during the first Vatican Council were based. Also striking in this context is the extent to which, theologically, Manning was largely self-taught.

Fr Pereiro shows how High Church principles and Evangelical piety continued to co-exist, awkwardly, in Manning until the late 1840s. At the same time, however, Manning was developing his formidable powers of synthesis, 'working the knowledge he acquired into a general scheme, always looking for the connections between ideas, trying to integrate principles and concepts into a coherent general vision of reality' (p. 45). Skilfully, the author reveals how that coherence was achieved after years of immense intellectual turmoil caused both by Manning's own internal mental wrestlings, notably around the time of his severe illness in 1847 , as well as by a variety of external factors coming in rapid succession. The latter included Newman's conversion in 1845, the appointment of Hampden to the see of Hereford in 1847, despite the protests of fourteen bishops of the Church of England, the Gorham judgement and the restoration of the Roman Catholic hierarchy in England and Wales in 1850.

The seven chapters of this study provide a fine balance between Manning's intellectual development in his Anglican years and the continuation of that development after his conversion. Of especial interest is the discussion of the background to the Vatican Council, and analysis of Manning's contribution to it, particularly the way in which his influence resulted in the issue of papal infallibility being given priority in the Council's debates.

Readers familiar with the earlier studies of Manning mentioned above will find this book particularly rewarding on numerous counts. Not least among these are the way in which Manning's unwavering conviction and sincerity are portrayed-and the manner in which his theological legacy is placed in a wider context. Fr Pereiro remarks (p.103) that "it would be no mean task to chart in detail the springs which fed Manning's thought". That task is precisely one that he achieves admirably in this scholarly work.

Cardinal Manning: An Intellectual Biography by James Pereiro [Clarendon Press, Oxford, 1999, ISBN 0-19-815089-X.] 